\title{
Growth Hormone Response to Oral Glucose Load: From Normal to Pathological Conditions
}

\author{
Mirella Hage Peter Kamenický Philippe Chanson
}

Assistance Publique-Hôpitaux de Paris, Hôpital de Bicêtre, Service d'Endocrinologie et des Maladies de la Reproduction, Centre de Référence des Maladies Rares de l'Hypophyse, Institut National de la Santé et de la Recherche Médicale (Inserm) U1185, Université Paris-Sud, Université Paris-Saclay, Le Kremlin-Bicêtre, France

\section{Keywords}

Growth hormone - Oral glucose tolerance test - Biological variability · Paradoxical growth hormone response

\begin{abstract}
The exact physiological basis of acute growth hormone (GH) suppression by oral glucose is not fully understood. Glucosemediated increase in hypothalamic somatostatin seems to be the most plausible explanation. Attempts to better understand its underlying mechanisms are compromised by species disparities in the response of $\mathrm{GH}$ to glucose load. While in humans, glucose inhibits $\mathrm{GH}$ release, the acute elevation of circulating glucose levels in rats has either no effect on GH secretion or may be stimulatory. Likewise, chronic hyperglycemia alters $\mathrm{GH}$ release in both humans and rats nonetheless in opposite directions. Several factors influence nadir $\mathrm{GH}$ concentrations including, age, gender, body mass index, pubertal age, and the type of assay used. Besides the classical suppressive effects of glucose on $\mathrm{GH}$ release, a paradoxical GH increase to oral glucose may be observed in around one third of patients with acromegaly as well as in various other disorders. Though its pathophysiology is poorly characterized, an altered interplay between somatostatin and
\end{abstract}

๑ 2019 S. Karger AG, Basel
GH-releasing hormone has been suggested and a link with pituitary ectopic expression of glucose-dependent insulinotropic polypeptide receptor has been recently demonstrated. A better understanding of the dynamics mediating $\mathrm{GH}$ response to glucose may allow a more optimal use of the OGTT as a diagnostic tool in various conditions, especially acromegaly.

(c) 2019 S. Karger AG, Basel

\section{Introduction}

Growth hormone (GH) secretory pattern in rodents and in humans is pulsatile and sexually dimorphic $[1,2]$. GH secretion is classically orchestrated by 2 hypothalamic hormones: GH-releasing hormone (GHRH) and somatotropin release-inhibiting factor (SRIF), which exhibit a stimulatory and an inhibitory effect, respectively, on the somatotroph cells in the anterior pituitary [3]. Ghrelin, a gut-derived peptide and a ligand of the GH secretagogue receptor is increasingly recognized as the third regulator of $\mathrm{GH}$ secretion with a marked stimulatory action. In addition to its excitatory impact on GHRH release and a weaker inhibitory action on somatostatin,

\section{KARGER}

E-Mail karger@karger.com www.karger.com/nen
Philippe Chanson, MD, MS

Service d'Endocrinologie et des Maladies de la Reproduction Hôpital de Bicêtre

FR-94275 Le Kremlin Bicêtre (France)

E-Mail philippe.chanson@aphp.fr 


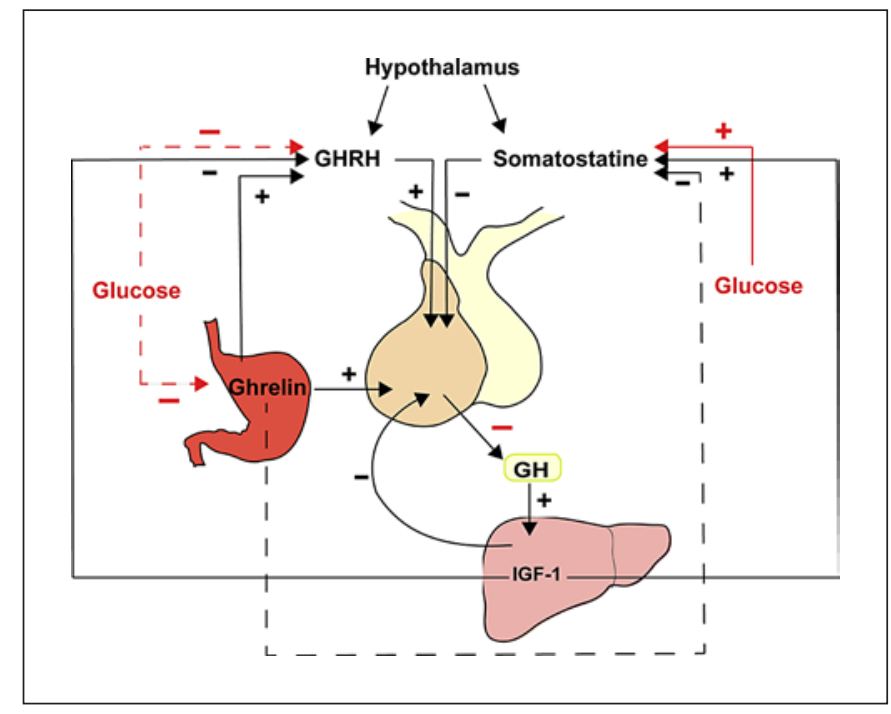

Fig. 1. Schematic overview of the potential pathophysiological impact of glucose on GH. Black arrows indicate the stimulatory $(+)$ and inhibitory (-) actions of the different regulators of GH secretion. Red arrows indicate the stimulatory $(+)$ and inhibitory $(-)$ impact of glucose on GH regulators and GH secretion. Dashed lines indicate a weak effect. GH, growth hormone; GHRH, GHreleasing hormone; IGF-1, insulin growth factor 1 .

ghrelin directly stimulates GH secretion from pituitary somatotroph cells $[4,5]$. IGF-1 has a major inhibitory action on GH release through feedback at both the hypothalamus and the pituitary. It seems to inhibit both spontaneous and GHRH-stimulated GH release and displays stimulatory effects on somatostatin neurons [6] (Fig. 1). A number of factors including neuropeptides, neurotransmitters, peripheral hormones such as leptin, sexual steroids, glucocorticoids and various metabolic signals are implicated in the complex regulation of GH release.

The impact of glucose on GH secretion has been demonstrated in the early 1960s [7] and confirmed later by many other authors. It is well established that hypoglycemia stimulates GH release [8] and hence, insulin-induced hypoglycemia is used clinically to assess the integrity of GH secretion.

On the other hand, oral glucose administration suppresses GH secretion and likewise is the standard method for assessing inhibitory control of GH release [9]. Failure of GH suppression is characteristic of active acromegaly, though it can also be observed in other pathological conditions such as chronic kidney disease, liver disease, and anorexia nervosa (Table 1).

GH Response to Oral Glucose Load
Table 1. Conditions associated with a lack of suppression of GH to oral glucose load

- Adolescence

- Anorexia nervosa

- Chronic hepatitis

- Diabetes mellitus

- Hyperthyroidism

- Obesity

- Oral estrogen treatment

- Uremia

The purpose of this review is to highlight the known mechanisms underlying the effects of glucose on GH in normal and pathological conditions and summarize the factors influencing $\mathrm{GH}$ response to glucose overload in healthy individuals and patients with acromegaly.

\section{Methodology for Literature Search}

A PubMed search was conducted from the period of 1946 until 2018 using the search terms: "acromegaly," "diabetes," "glucose," "hyperglycemia," "growth hormone," "growth hormone releasing hormone," "nadir growth hormone," "oral glucose tolerance test," "paradoxical response," and "somatostatin."

The above terms were used in mixed combinations. Boolean operators and truncations were used to expand our search results. References from the selected pertinent articles, and publications available in the authors' libraries were also used.

\section{GH Response to Oral Glucose and to Chronic Hyperglycemia}

The precise mechanisms of GH suppression by oral glucose are not completely understood. Attempts to determine the exact mechanisms are compromised by species disparities observed in the physiological responses of $\mathrm{GH}$ to glucose overload or deprivation. In this section, we briefly review existing data in humans and rodents in both acute and chronic hyperglycemia.

\section{Acute Hyperglycemia}

Following oral glucose administration in humans, a transient suppression of plasma GH levels for $2-3 \mathrm{~h}$ is observed followed by a delayed rise occurring at $3-5 \mathrm{~h}$ post 
Table 2. Effects of acute hyperglycemia on GH and GH modulators in in vitro and in vivo animal studies

\begin{tabular}{|c|c|c|c|}
\hline Author, years & Cell or animal model & Experimental design & Findings \\
\hline Page et al. [20], 1987 & $\begin{array}{l}\text { Anterior pituitary cells from } \\
\text { male Wistar rats }\end{array}$ & 5 vs. $50 \mathrm{~mm}$ glucose & $\begin{array}{l}\leftrightarrow \text { Basal GH release }(30 \mathrm{~min}) \\
\leftrightarrow \text { GH release after } 10^{-8} \mathrm{M} \text { GHRH }(3 \mathrm{~h})\end{array}$ \\
\hline Caldwell et al. [21], 1989 & Rat anterior pituitary cells & 5 vs. $20 \mathrm{~mm}$ glucose & $\leftrightarrow \mathrm{GH}$ release after GHRH \\
\hline Renier et al. [22], 1991 & $\begin{array}{l}\text { Anterior pituitary cells from } \\
\text { male Sprague-Dawley rats }\end{array}$ & $\begin{array}{l}6 \mathrm{vs} .22 \mathrm{mM} \text { glucose for } 72 \mathrm{~h} \\
\text { then incubation of both conditions } \\
\text { with } 22 \mathrm{mM} \text { for } 2 \mathrm{~h}\end{array}$ & $\begin{array}{l}6 \mathrm{mM}: \leftrightarrow \text { basal GH release } \\
\leftrightarrow \mathrm{GH} \text { release after GHRH } \\
22 \mathrm{mM}: \uparrow \text { basal GH release } \\
\uparrow \text { intracellular GH content } \\
\downarrow \text { GH release after } 200 \mathrm{ng} \text { GHRH } \\
\downarrow \text { GH inhibition by SRIF } \\
\text { Restoration of GH release after } 24 \text { h exposure to } 6 \\
\text { mM glucose }\end{array}$ \\
\hline Murao et al. [23], 1994 & Male Wistar rats & $\begin{array}{l}\text { NS vs. } 1 \mathrm{~mL} 50 \% \text { glucose administered } \\
\text { IV q } 20 \mathrm{~min} \text { for } 5 \mathrm{~h}\end{array}$ & $\begin{array}{l}\downarrow \text { in GHRH }(200 \mathrm{ng}) \text {-stimulated GH release } \\
\uparrow \text { in hypothalamic SRIF mRNA } \\
\uparrow \text { in hypothalamic GHRH mRNA content }\end{array}$ \\
\hline
\end{tabular}

GH, growth hormone; GHRH, GH-releasing hormone; IV, intravenous; NS, normal saline; SRIF, somatostatin.

glucose ingestion $[7,10]$. This initial suppression seems to be related to a glucose-mediated increase in hypothalamic somatostatin release. Evidence supporting this hypothesis emerges from the findings that in healthy individuals, $\mathrm{GH}$ secretion in response to GHRH or GH secretagogue is diminished after an oral glucose load [11, 12]. Furthermore, the inhibitory effect of glucose is reversed with the acetylcholinesterase inhibitor pyridostigmine, a substance thought to suppress somatostatin release from the hypothalamus [13]. These findings support the hypothesis that oral glucose load is associated with a somatostatin release into the hypophyseal portal blood suppressing GH levels. The delayed GH rise would result from a decrease in somatostatinergic tone and hence an increase in GHRH [14]. Subsequently, the available pituitary stores of GH are released leading to a rebound rise in GH.

Recently, the involvement of ghrelin in the regulation of post-glucose GH has been suggested [15]. In a multivariate analysis, ghrelin was the only predictor for fasting and peak GH levels following oral glucose load in women [16] (Fig. 1). Of note, some authors have shown that the nadir GH levels obtained following glucose intake are not specific to glucose and also occur after water ingestion or even spontaneous GH measures. They showed that glucose rather inhibits spontaneous GH surges $[17,18]$. The exact molecular mechanisms by which glucose modulates $\mathrm{GH}$ release are yet to be determined.

Stanley et al. [19] have demonstrated that changes in glucose and specifically hypoglycemia activate GHRH neurons through the glucokinase activation in EGFPtagged ribosomal protein constructed mice. However, the role of direct glucose sensing in GHRH neurons on GH modulation is questionable, since hypoglycemia in mice causes a reduction in $\mathrm{GH}$ release.

While in humans, glucose load inhibits GH release, the acute elevation of circulating glucose levels in rats has either no effect on GH secretion or may be stimulatory (Table 2). A possible direct pituitary action of glucose cannot be ruled out. Although little effect of high glucose on basal and GHRH-stimulated GH levels has been observed in rat anterior pituitary cells in static incubation [20] or in perifusion [21], sustained glucose elevation $(72 \mathrm{~h})$ increased GH secretion in cultured cells [22]. In in vivo rat models, GH secretion is inhibited by both hypo and hyperglycemia most likely via the stimulation of somatostatin release. Both acute hypo- and hyperglycemia stimulate SRIF mRNA, while GHRH mRNA is stimulated only by hyperglycemia [23].

\section{Chronic Hyperglycemia}

Chronic hyperglycemia, manifested clinically by diabetes mellitus, alters GH release in both humans and rats though in opposite directions.

Type 1 diabetes mellitus (T1D) patients display an increased pulsatile GH secretion and an exaggerated GH increase after GHRH administration [24, 25]. Failure of T1D patients to increase their $\mathrm{GH}$ responses to GHRH following pyridostigmine treatment suggests a decrease in hypothalamic somatostatin release in these patients [26]. Evi- 
Table 3. Effects of chronic hyperglycemia on GH and GH modulators in in vitro and in vivo animal studies

\begin{tabular}{|c|c|c|c|}
\hline Author, years & Animal model & Experimental design & Findings \\
\hline $\begin{array}{l}\text { Patel et al. [33], } \\
1980\end{array}$ & Male Sprague Dawley rats & $\begin{array}{l}\text { STZ } 55 \mathrm{mg} / \mathrm{kg} \\
\text { Assessment at } 24 \mathrm{~h}, 2 \text { weeks, } 26 \text { weeks }\end{array}$ & $\uparrow$ hepatic portal and peripheral blood SRIF at 2 and 26 weeks \\
\hline $\begin{array}{l}\text { Tannenbaum [37], } \\
1981\end{array}$ & Male Sprague Dawley rats & $\begin{array}{l}\text { STZ } 65 \mathrm{mg} / \mathrm{kg} \\
\text { Assessment at } 18 \mathrm{~h}, 4 \text { weeks }\end{array}$ & $\begin{array}{l}\downarrow \text { in mean 6-h serum GH and pulse amplitude at } 18 \mathrm{~h}, 4 \text { weeks } \\
\text { Restoration of GH levels and pulses after SRIF anti-serum }\end{array}$ \\
\hline $\begin{array}{l}\text { Bluet-Pajot et al. [36], } \\
1983\end{array}$ & Male Wistar rats & $\begin{array}{l}\mathrm{STZ} 65 \mathrm{mg} / \mathrm{kg} \\
\text { Assessment at } 15 \text { days }\end{array}$ & $\begin{array}{l}\downarrow \text { pituitary GH content } \\
\leftrightarrow \text { basal GH levels } \\
\leftrightarrow \text { GH inhibition by SRIF } \\
\text { Partial restoration of pituitary GH content with insulin treat- } \\
\text { ment }\end{array}$ \\
\hline $\begin{array}{l}\text { Olchovsky et al. [39], } \\
1990\end{array}$ & Male Sprague Dawley rat & $\begin{array}{l}\mathrm{STZ} 100 \mathrm{mg} / \mathrm{kg} \\
\text { Assessment at } 17-20 \text { days }\end{array}$ & $\begin{array}{l}\downarrow \text { basal GH levels } \\
\downarrow \text { pituitary GH content } \\
\downarrow \text { hypothalamic GHRH mRNA } \\
\downarrow \text { in SRIF receptor concentration } \\
\text { Restoration at least partially of these parameters after insulin } \\
\text { treatment }\end{array}$ \\
\hline $\begin{array}{l}\text { Joanny et al. [35], } \\
1992\end{array}$ & Male Sprague Dawley rats & $\begin{array}{l}\text { STZ } 65 \mathrm{mg} / \mathrm{kg} \\
\text { Assessment at } 5,9 \text {, and } 30 \text { days }\end{array}$ & $\begin{array}{l}\downarrow \text { basal GH levels } \\
\uparrow \text { SRIF at } 9 \text { and } 30 \text { days } \\
\uparrow \text { in SRIF release from hypothalamic fragments after } 9 \text { days at } \\
10 \text { and } 33 \text { mM of glucose }\end{array}$ \\
\hline $\begin{array}{l}\text { Ndon et al. [34], } \\
1992\end{array}$ & Diabetic BB/Worcester rat & & $\begin{array}{l}\downarrow \mathrm{GHRH}(500 \mathrm{ng} / \mathrm{kg}) \text { - stimulated GH release GHRH } \\
\text { Restoration of attenuated GH response to GHRH after SRIF- } \\
\mathrm{Ab} \\
\leftrightarrow \mathrm{GH} \text { content of pituitaries }\end{array}$ \\
\hline $\begin{array}{l}\text { Busiguina et al. [32], } \\
2000\end{array}$ & Male Wistar rat & $\begin{array}{l}\text { STZ } 65 \text { and } 100 \mathrm{mg} / \mathrm{kg} \\
\text { Assessment at } 3 \text { weeks, } 2 \text { months }\end{array}$ & $\begin{array}{l}\downarrow \text { in pituitary GH mRNA at } 2 \text { months } \\
\downarrow \text { hypothalamic GHRH mRNA at } 3 \text { weeks and } 2 \text { months } \\
\downarrow \text { hypothalamic SRIF mRNA at } 3 \text { weeks and } 2 \text { months }\end{array}$ \\
\hline $\begin{array}{l}\text { Bédard et al. [31], } \\
2008\end{array}$ & Male Sprague Dawley rats & $\begin{array}{l}\text { STZ } 65 \text { and } 100 \mathrm{mg} / \mathrm{kg} \\
\text { Assessment at 2, 21, } 60 \text { days }\end{array}$ & $\begin{array}{l}\downarrow \text { hypothalamic GHRH mRNA at } 2,21 \text { and } 60 \text { days } \\
\uparrow \text { in } 2.5 \mathrm{~kb} \text { pituitary GHRH mRNA at } 2 \text { and } 21 \text { days }\end{array}$ \\
\hline
\end{tabular}

Ab, antibody; STZ, streptozotocin; GH, growth hormone; GHRH, GH-releasing hormone; IV, intravenous; NS, normal saline; SRIF, somatostatin.

dence suggests that portal vein insulin deficiency contributes to $\mathrm{GH}$ dysregulation by downregulating hepatic $\mathrm{GH}$ receptors explaining the state of "GH resistance" in this population [27]. Furthermore, decreased hepatic production of IGF-1 observed in diabetic patients results in excess GH secretion by lack of negative feedback action [28].

Data in patients with T2D have yielded conflicting results. Spontaneous GH secretion as well as GHRH stimulated GH may be increased, normal or decreased [3]. One of the main determinants of these differences was obesity where obese T2D patients display significantly reduced $\mathrm{GH}$ responses to GHRH compared to lean individuals and to non-obese diabetic patients $[29,30]$.
Diabetes mellitus in rodents seems to reduce pulsatile GH secretion and attenuate GH secretory response to GHRH (Table 3). In streptozotocin (STZ)-induced type 1 diabetic rat models, $\mathrm{GH}$ secretion is decreased along with a reduction in GHRH mRNA and SRIF mRNA, suggesting a differential effect of acute and chronic hyperglycemia on hypothalamic-pituitary GH regulation [31, 32]. Hyperglycemia seems to directly impact pituitary somatotroph cells by blunting GH release in response to GHRH or by increasing somatostatin release [33-36]. This attenuated GH response is restored after treatment with somatostatin antiserum or pentobarbital anesthesia, which presumably suppresses somatostatin release [37, 38]. In isolated pituitary cells from 


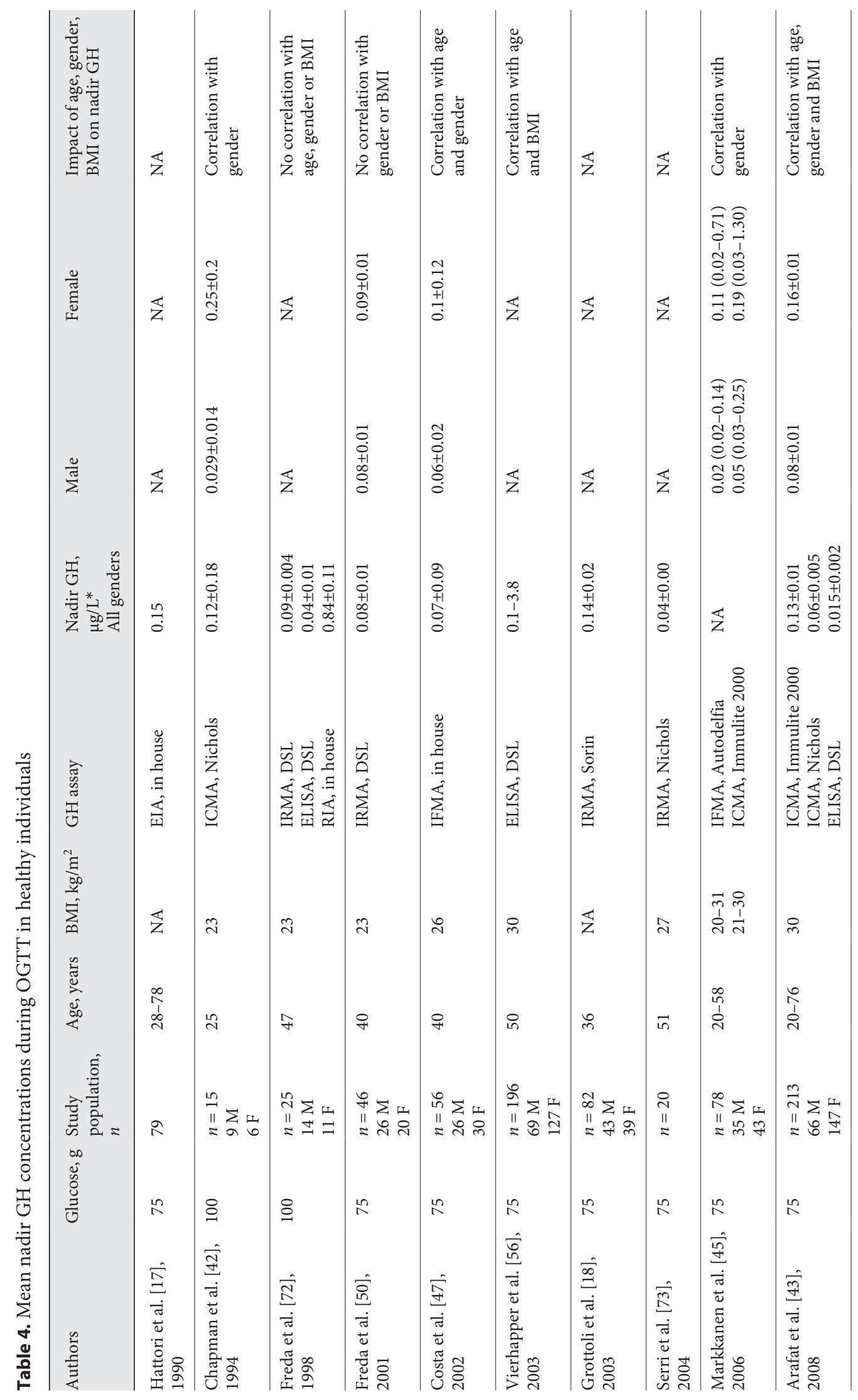




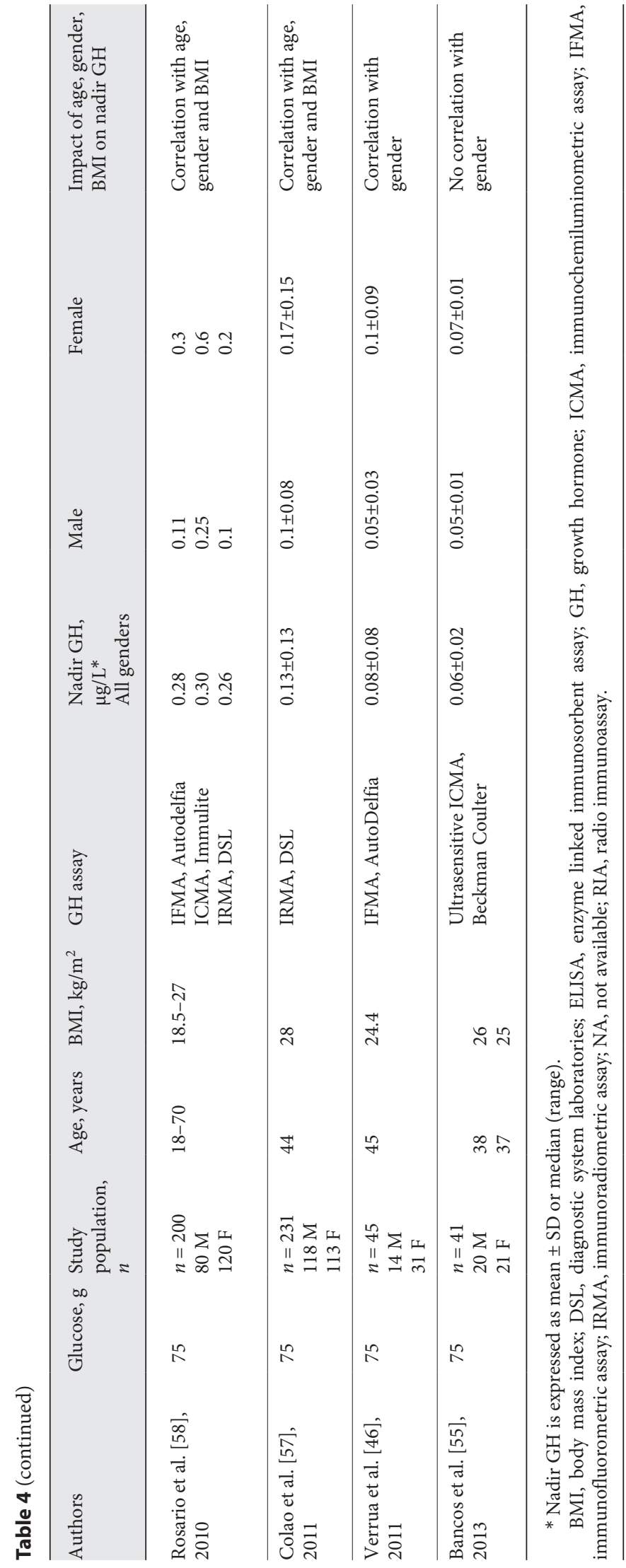

GH Response to Oral Glucose Load
STZ-induced diabetic mice, a decrease in basal GH levels and in GHRH-stimulated GH release as well as a resistance to inhibitory action of SRIF on GHRH stimulated GH release have been reported [39]. However, STZ dose and time of assessment after treatment may alter $\mathrm{GH}$ release [40] and should be taken into account when interpreting results. Indeed, Liu et al. [41] have demonstrated that high STZ dose (100-200 mg/kg) impairs GH secretion by blocking GH secretory granules in somatotroph cells often inducing cell rupture. This suggests that some of the decrease in pituitary GH release in high dose STZ-treated rats could be secondary to the toxic destruction of the somatotroph cells.

\section{Factors Influencing GH Suppression to Oral Glucose}

Nadir GH concentrations are influenced by physiological factors such as age, gender, and body mass index (BMI) and vary according to the $\mathrm{GH}$ assay used. Table 4 lists the mean nadir GH in different studies investigating plasma GH after OGTT in healthy subjects by different GH assays.

Gender: A higher nadir level of GH during OGTT has been observed in women compared to men in healthy populations [42-47] and in patients with acromegaly [48, 49]. These higher GH concentrations after OGTT seem to be a consequence of higher basal values rather than a lower suppressive effect of glucose. Indeed, greater basal $\mathrm{GH}$ concentrations have been documented in premenopausal women and in women treated with oral estrogens [50-52]. However, these gender-specific differences have not been consistent in all studies [50, 53-55].

\section{Body Mass Index}

Similarly, an inverse relationship between GH concentrations and $\mathrm{BMI}$ has been demonstrated $[43,56,57]$ especially in obese subjects with a BMI $>30 \mathrm{~kg} / \mathrm{m}^{2}$ [58]. In 381 subjects with normal pituitary function, BMI was the major determinant of $\mathrm{GH}$ nadirs following oral glucose. When stratified according to BMI, GH nadirs were significantly different across all groups [59]. In general, investigations in obese subjects showed reduction in both spontaneous $[60,61]$ and stimulated GH secretion [62]. Specifically, the mass of GH secreted per burst is diminished and the metabolic clearance rate of $\mathrm{GH}$ is increased [61].

\section{Age}

$\mathrm{GH}$ secretion decreases with age at a rate of $14 \%$ per decade [60]. The decrease in GH results from a marked reduction in GH pulse amplitude rather than frequency [63] most likely related to a relative deficiency in GHRH and 
ghrelin secretion and an increase in SRIF release [64]. Likewise, some authors have reported lower nadir GH levels in older individuals $[47,57,65]$. The use of age-adjusted GH and nadir GH cut-off values to define biochemical remission of acromegaly following surgery has been suggested [65]. However, the effect of age on GH nadir levels has not been consistently observed across all studies [50,59].

\section{Pregnancy}

Only a few reports have evaluated GH suppression during OGTT in pregnancy $[66,67]$. Interference of circulating placental GH often results in falsely elevated $\mathrm{GH}$ levels in competitive immunoassays [68] and either falsely suppressed or high GH values in immunometric assays [69].

\section{Pubertal Stage}

The influence of pubertal stage on GH nadirs after oral glucose has been investigated. Higher nadir GH levels were reported in mid-pubertal girls and boys compared to children in other pubertal stages [70].

\section{Fat Redistribution}

In HIV-infected patients, those with lipodystrophy did not display a rebound of GH during a 3-h OGTT suggesting that in the setting of fat redistribution, patients exhibit prolonged post glucose GH suppression [71].

\section{GH Assays}

With the progression from older polyclonal radio-immunoassay to more sensitive and specific GH assays, lower GH cut-off values have been suggested [72].

The influence of assay methods on nadir GH concentrations has been repeatedly demonstrated during the last decades [43-45, 72, 73] (Table 4). Although nadir GH levels results from all assays strongly correlate, mean $\mathrm{GH}$ concentrations vary widely hindering the establishment of optimal normative data. For instance, Arafat et al. [43] demonstrated that mean GH concentrations obtained with the immunochemiluminetric assay, Immulite, were two to threefold higher than the Nichols immunochemiluminetric assay and six-fold higher than the ELISA assay. Furthermore, the use of different standard preparations for $\mathrm{GH}$ calibration also accounts for inter-assay variability in different laboratories. Finally, the reporting of results in biological activity (mUI/L) or mass units $(\mu \mathrm{g} / \mathrm{L})$ together with the use of variable conversion factors constitutes an additional cause for assay variability. Currently, all GH assays should be calibrated using the recombinant calibrator $98 / 574$ and all GH assay results should be reported in mass units $[74,75]$.
Table 5. Conditions associated with a paradoxical increase of GH to oral glucose load

- Acromegaly

- Anorexia nervosa

- Anterior hypothalamic tumors

- Chronic liver disease

- Extrapituitary acromegaly

- Impaired glucose tolerance/diabetes

- Intermittent porphyria

- Newborns

- Protein malnutrition

- Puberty

- Renal failure

- Turner's syndrome

\section{OGTT in the Diagnosis of Acromegaly}

In contrast to healthy subjects, oral glucose fails to suppress GH in acromegaly. The criteria for GH suppression after oral glucose have evolved in recent years with the availability of more sensitive techniques. However, despite several reports highlighting the unmet need for standardization of GH assays during the last decades, little progress has been noted to date [76-78]. The cutoff for nadir GH after OGTT seems to largely depend on the GH assay used [43]. The $1 \mu \mathrm{g} / \mathrm{L}$ cutoff used to define acromegaly probably needs to be reduced to $0.3 \mu \mathrm{g} / \mathrm{L}$ or even lower [79-81]. Indeed, with the generalized use of sensitive assays (chemiluminescence or fluorometric assays with very low detection limits $[0.10-0.30 \mu \mathrm{g} / \mathrm{L}])$, a few patients with clear clinical signs of acromegaly and high IGF-I levels, may demonstrate suppressed GH levels $(<1$ $\mu \mathrm{g} / \mathrm{L}$ during the OGTT) due to their low GH output [43, 82-85].

Of note, in around one third of patients with acromegaly, GH levels may paradoxically increase in response to oral glucose $[84,86-90]$. This phenomenon was initially described by Beck et al. [91] in acromegaly patients and later reported in several other conditions and disorders (Table 5). There is currently no agreement on the criteria to define a paradoxical GH response pattern. Indeed, some studies regarded an early rise of GH to oral glucose as opposed to a normal suppression as a paradoxical response. Other reports described an increase of more than $20-100 \%$ above basal levels (Table 6). It should be noted however that most reports were early studies, involving different study populations with various pathologies $[17$, 92-94]. The OGTT was not standardized, as 50-100 g of oral glucose was administered and variable GH assays 
Table 6. Studies of paradoxical GH response to OGTT

\begin{tabular}{|c|c|c|c|c|}
\hline Authors & Population (cases) & Glucose & Paradoxical response & Prevalence, $\%$ \\
\hline Beck et al. [91], 1966 & 22 pituitary tumors & $100 \mathrm{~g}$ & $\uparrow \mathrm{GH}$ & $\begin{array}{l}2 \text { acromegaly (9) } \\
1 \text { optic glioma }\end{array}$ \\
\hline Hunter et al. [92], 1966 & $\begin{array}{l}24 \text { controls } \\
64 \text { diabetes }\end{array}$ & $50 \mathrm{~g}$ & Early $\uparrow \mathrm{GH}<60 \mathrm{~min}$ & 2 diabetes (8) \\
\hline Becker et al. [93], 1969 & $\begin{array}{l}4 \text { controls } \\
14 \text { active chronic hepatitis }\end{array}$ & $0.75 \mathrm{~g} / \mathrm{kg}$ & Early $\uparrow \mathrm{GH}<45 \mathrm{~min}$ & 7 hepatitis $(50)$ \\
\hline Grecu et al. [94], 1982 & $\begin{array}{l}27 \text { controls } \\
24 \text { abnormal OGTT }\end{array}$ & $100 \mathrm{~g}$ & $\uparrow>2 \times$ baseline $+>5 \mathrm{ng} / \mathrm{mL}<120 \mathrm{~min}$ & 7 abnormal OGTT (29) \\
\hline Hattori et al. [17], 1990 & $\begin{array}{l}37 \text { controls } \\
16 \text { acromegaly }\end{array}$ & $75 \mathrm{~g}$ & $>50 \%$ from baseline level at $30-60 \mathrm{~min}$ & 3 controls $(8)$ \\
\hline Landis et al. [84], 1990 & 22 acromegaly & $100 \mathrm{~g}$ & $\uparrow \mathrm{GH}$ & 2 acromegaly (9) \\
\hline Adams et al. [86], 1993 & 19 acromegaly & NA & $\uparrow \mathrm{GH}$ & 3 acromegaly (16) \\
\hline Buchfelder et al. [87], 1999 & 145 acromegaly & NA & $\uparrow \mathrm{GH}$ & 38 acromegaly (26) \\
\hline Occhi et al. [88], 2011 & 21 acromegaly & $75 \mathrm{~g}$ & $\begin{array}{l}\uparrow \mathrm{GH}(61 \pm 24 \%) \text { within } 30-90 \mathrm{~min} \\
\uparrow \mathrm{GH}>90 \mathrm{~min} \text { in one patient }\end{array}$ & 7 acromegaly (33) \\
\hline Scaroni et al. [89], 2018 & 496 acromegaly & $75 \mathrm{~g}$ & Peak to basal GH ratio $>120 \%$ & 184 acromegaly (37) \\
\hline Mukai et al. [90], 2018 & 64 acromegaly & $75 \mathrm{~g}$ & $\uparrow \mathrm{GH}$ by $30 \%$ from baseline & 19 acromegaly (30) \\
\hline
\end{tabular}

GH, growth hormone; IGT, impaired glucose tolerance; IDDM, insulin-dependent diabetes mellitus; OGTT, oral glucose tolerance test.

were used. Additionally, data on the reproducibility of the paradoxical GH response to oral glucose are lacking, as it may be influenced by the well-documented spontaneous GH fluctuations in acromegalic patients [95].

The paradoxical GH response to OGTT may have clinical and prognostic significance in patients with acromegaly. We have recently reported that a paradoxical GH response to oral glucose occurred in patients with GNASmutation negativetumors, mainlyof the pure somatotroph densely granulated phenotype and harboring high cytogenetic alterations $[96,97]$.

Very recently, a large study analyzed 496 patients with acromegaly and investigated the association between glucose-induced GH response and endocrine profiles, clinical manifestations, and response to therapy [89]. Patients in the paradoxical response group were older, had smaller and less invasive tumors, and showed a better response to somatostatin analogues. Therefore, a paradoxical rise of $\mathrm{GH}$ to oral glucose in acromegaly may reflect some important biological characteristics of pituitary tumors.

As for the underlying mechanisms of the paradoxical $\mathrm{GH}$ response, to date they remain incompletely characterized. An altered interplay between somatostatin and
GHRH has been suggested [98] but not well documented. Recently, in analogy to food-dependent Cushing's syndrome [99-101], a role for ectopic expression of the glucose-dependent insulinotropic polypeptide receptor $(G I P R)$ in somatotroph adenomas for mediating the paradoxical GH response to OGTT has been evoked [88, $102]$. We have recently shown that among 41 pituitary adenomas, all 10 samples from patients with paradoxical GH responses displayed ectopic GIPR expression [96]. In a previous study, GIP infusion was shown to increase GH secretion in 2 patients with acromegaly whose $\mathrm{GH}$ showed a paradoxical response to OGTT [102]. Furthermore, in GH3 cells transfected with GIPR, GIP stimulation increased cAMP levels and GH transcription [88]. Indeed, acromegalic patients exhibiting paradoxical GH responses to oral glucose load increased their plasma GH levels in response to intravenous GIP stimulation. Furthermore, loss of this paradoxical GH response when glucose was administered intravenously supported the hypothesis of the implication of a gastrointestinal hormone [102]. In addition, GIP stimulation of GIPR-expressing somatotroph adenomas in primary culture increased GH release in $80 \%$ of these adenomas, with $60 \%$ reaching statistical significance [103]. 


\section{OGTT in the Follow-Up of Acromegaly}

Disease control in acromegaly is defined by the normalization of IGF-1 levels and GH nadir $<0.4 \mu \mathrm{g} / \mathrm{L}$ after OGTT using ultrasensitive assays [104]. As previously mentioned, GH nadir levels during an OGTT are affected by multiple factors such as biological factors, analytical variations in addition to treatment-specific differences in biochemical responses. These factors result in discordant IGF-1 and GH levels and should be considered when interpreting results of the OGTT test.

Specifically, the utility of a GH nadir during OGTT in monitoring disease activity in somatostatin analogue treated patients has been questioned $[43,105]$ and is generally not recommended $[104,106]$. In these patients, IGF-1 levels do not seem to correlate with GH secretion as opposed to healthy individuals and to patients with acromegaly not receiving somatostatin analogues. Therefore, in this patient population, normalizing IGF-1 has been recommended as the goal of therapy and suggested as the best reflection of disease activity [104].

In contrast, another group has questioned the validity of IGF-1 as an adequate marker of disease activity in somatostatin analogue-treated patients, as somatostatin analogues may exert a suppressive effect on hepatic IGF1 production resulting in normal IGF-1 levels despite continued disease activity induced by circulating GH [107109]. The authors reported significantly higher GH nadir levels along with worse symptoms and quality of life in controlled patients treated with somatostatin analogues compared to surgery despite comparable IGF-I and fasting GH levels [109]. Dose escalation of somatostatin analogues minimized the discordance between IGF-1 and nadir GH levels with, however, no improvement in qual- ity of life [108]. Furthermore, higher GH nadir levels after an OGTT as well as after mixed meals were observed in patients treated with somatostatin analogues compared to patients successfully treated with surgery and matched to IGF-1 levels suggesting a residual disease activity in somatostatin analogue treated patients despite normalized IGF-I levels [107]. The authors thus conclude that measuring GH levels during OGTT may unmask insufficient disease control with somatostatin analogues despite normalized IGF-I levels.

\section{Conclusion}

Although the impact of glucose on GH secretion has been known since decades, the exact underlying mechanisms are still elusive. Besides the classical suppressive effects on GH release, glucose exhibits stimulatory effects termed "paradoxical" reported in acromegaly and in various other disorders. The paradoxical response of $\mathrm{GH}$ to oral glucose in acromegaly may help delineate specific phenotypic tumor characteristics that may influence therapy. Further understanding of the dynamics mediating GH response to glucose may allow the better use of the OGTT as a diagnostic tool in various conditions especially acromegaly. Potential biological factors modifying $\mathrm{GH}$ secretions and $\mathrm{GH}$ assays should always be taken into account in the interpretation of GH values during OGTT.

\section{Disclosure Statement}

The authors declare that they have no conflicts of interest to disclose.

\section{References}

1 Tannenbaum GS, Martin JB. Evidence for an endogenous ultradian rhythm governing growth hormone secretion in the rat. Endocrinology. 1976 Mar;98(3):562-70.

2 Jaffe CA, Ocampo-Lim B, Guo W, Krueger K, Sugahara I, DeMott-Friberg R, et al. Regulatory mechanisms of growth hormone secretion are sexually dimorphic. J Clin Invest. 1998 Jul;102(1):153-64.

3 Giustina A, Veldhuis JD. Pathophysiology of the neuroregulation of growth hormone secretion in experimental animals and the human. Endocr Rev. 1998 Dec;19(6):717-97.
4 Murray PG, Higham CE, Clayton PE. 60 YEARS OF NEUROENDOCRINOLOGY: The hypothalamo-GH axis: the past 60 years. J Endocrinol. 2015 Aug;226(2):T123-40.

5 Baragli A, Lanfranco F, Allasia S, Granata R, Ghigo E. Neuroendocrine and metabolic activities of ghrelin gene products. Peptides. 2011 Nov;32(11):2323-32.

6 Steyn F, Tolle V, Chen C, Epelbaum J. Neuroendocrine Regulation of Growth Hormone Secretion. Compr Physiol. 2016 Mar 15;6(2): 687-735.
7 Roth J, Glick SM, Yalow RS, Berson SA. Secretion of human growth hormone: physiologic and experimental modification. Metabolism. 1963 Jul;12:577-9.

8 Roth J, Glick SM, Yalow RS, Bersonsa. Hypoglycemia: a potent stimulus to secretion of growth hormone. Science. 1963 May; 140(3570):987-8.

9 Hunter WM, Willoughby JM, Strong JA. Plasma insulin and growth hormone during 22hour fasts and after graded glucose loads in six healthy adults. J Endocrinol. 1968 Mar;40(3): 297-311. 
10 Yalow RS, Goldsmith SJ, Berson SA. Influence of physiologic fluctuations in plasma growth hormone on glucose tolerance. Diabetes. 1969 Jun;18(6):402-8.

11 Masuda A, Shibasaki T, Nakahara M, Imaki T, Kiyosawa Y, Jibiki K, et al. The effect of glucose on growth hormone (GH)-releasing hormone-mediated GH secretion in man. J Clin Endocrinol Metab. 1985 Mar;60(3):523-6.

12 Broglio F, Benso A, Gottero C, Prodam F, Grottoli S, Tassone F, et al. Effects of glucose, free fatty acids or arginine load on the $\mathrm{GH}$ releasing activity of ghrelin in humans. Clin Endocrinol (Oxf). 2002 Aug;57(2):265-71.

13 Peñalva A, Burguera B, Casabiell X, Tresguerres JA, Dieguez C, Casanueva FF. Activation of cholinergic neurotransmission by pyridostigmine reverses the inhibitory effect of hyperglycemia on growth hormone $(\mathrm{GH})$ releasing hormone-induced GH secretion in man: does acute hyperglycemia act through hypothalamic release of somatostatin? Neuroendocrinology. 1989 May;49(5):551-4.

14 Friend K, Iranmanesh A, Login IS, Veldhuis JD. Pyridostigmine treatment selectively amplifies the mass of GH secreted per burst without altering $\mathrm{GH}$ burst frequency, half-life, basal GH secretion or the orderliness of GH release. Eur J Endocrinol. 1997 Oct;137(4): $377-86$.

15 Nakagawa E, Nagaya N, Okumura H, Enomoto $\mathrm{M}, \mathrm{Oya} \mathrm{H}$, Ono F, et al. Hyperglycaemia suppresses the secretion of ghrelin, a novel growthhormone-releasing peptide: responses to the intravenous and oral administration of glucose. Clin Sci (Lond). 2002 Sep;103(3):325-8.

16 Pena-Bello L, Pertega-Diaz S, OuteiriñoBlanco E, Garcia-Buela J, Tovar S, SangiaoAlvarellos S, et al. Effect of oral glucose administration on rebound growth hormone release in normal and obese women: the role of adiposity, insulin sensitivity and ghrelin. PLoS One. 2015 Mar; 10(3):e0121087.

17 Hattori N, Shimatsu A, Kato Y, Koshiyama H, Ishikawa $\mathrm{Y}$, Assadian $\mathrm{H}$, et al. Growth hormone responses to oral glucose loading measured by highly sensitive enzyme immunoassay in normal subjects and patients with glucose intolerance and acromegaly. J Clin Endocrinol Metab. 1990 Mar;70(3):771-6.

18 Grottoli S, Razzore P, Gaia D, Gasperi M, Giusti M, Colao A, et al. Three-hour spontaneous GH secretion profile is as reliable as oral glucose tolerance test for the diagnosis of acromegaly. J Endocrinol Invest. 2003 Feb; 26(2):123-7.

19 Stanley S, Domingos AI, Kelly L, Garfield A, Damanpour S, Heisler L, et al. Profiling of Glucose-Sensing Neurons Reveals that GHRH Neurons Are Activated by Hypoglycemia. Cell Metab. 2013 Oct;18(4):596-607.

20 Page MD, Koppeschaar HP, Edwards CA, Dieguez C, Scanlon MF. Additive effects of growth hormone releasing factor and insulin hypoglycaemia on growth hormone release in man. Clin Endocrinol (Oxf). 1987 May;26(5): 589-95.
21 Caldwell G, Hart G, Kohner EM, Burrin JM. Growth hormone-releasing factor-induced growth hormone secretion from perifused rat anterior pituitary cells: lack of influence of glucose concentration, and normal responses in pituitary cells from diabetic animals. J Endocrinol. 1989 Sep;122(3):657-60.

22 Renier G, Serri O. Effects of acute and prolonged glucose excess on growth hormone release by cultured rat anterior pituitary cells. Neuroendocrinology. 1991 Nov;54(5):521-5.

23 Murao K, Sato M, Mizobuchi M, Nimi M, Ishida T, Takahara J. Acute effects of hypoglycemia and hyperglycemia on hypothalamic growth hormone-releasing hormone and somatostatin gene expression in the rat. Endocrinology. 1994 Jan;134(1):418-23.

24 Asplin CM, Faria AC, Carlsen EC, Vaccaro VA, Barr RE, Iranmanesh A, et al. Alterations in the pulsatile mode of growth hormone release in men and women with insulin-dependent diabetes mellitus. J Clin Endocrinol Metab. 1989 Aug;69(2):239-45.

25 Hayford JT, Danney MM, Hendrix JA, Thompson RG. Integrated concentration of growth hormone in juvenile-onset diabetes. Diabetes. 1980 May;29(5):391-8.

26 Ismail IS, Scanlon MF, Peters JR. Cholinergic control of growth hormone $(\mathrm{GH})$ responses to GH-releasing hormone in insulin dependent diabetics: evidence for attenuated hypothalamic somatostatinergic tone and decreased GH autofeedback. Clin Endocrinol (Oxf). 1993 Feb;38(2):149-57.

27 Leung KC, Doyle N, Ballesteros M, Waters MJ, Ho KK. Insulin regulation of human hepatic growth hormone receptors: divergent effects on biosynthesis and surface translocation. J Clin Endocrinol Metab. 2000 Dec; 85(12):4712-20.

28 Ohlsson C, Mohan S, Sjögren K, Tivesten A, Isgaard J, Isaksson $\mathrm{O}$, et al. The role of liverderived insulin-like growth factor-I. Endocr Rev. 2009 Aug;30(5):494-535.

29 Giustina A, Bresciani E, Tassi C, Girelli A, Valentini U. Effect of pyridostigmine on the growth hormone response to growth hormone-releasing hormone in lean and obese type II Diabetic patients. Metabolism. 1994 Jul;43(7):893-8.

30 Kopelman PG, Mason AC, Noonan K, Monson JP. Growth hormone response to growth hormone releasing factor in diabetic men. Clin Endocrinol (Oxf). 1988 Jan;28(1):33-8.

31 Bédard K, Strecko J, Thériault K, Bédard J, Veyrat-Durebex C, Gaudreau P. Effects of a high-glucose environment on the pituitary growth hormone-releasing hormone receptor: type 1 diabetes compared with in vitro glucotoxicity. Am J Physiol Endocrinol Metab. 2008 Apr;294(4):E740-51.

32 Busiguina S, Argente J, García-Segura LM, Chowen JA. Anatomically specific changes in the expression of somatostatin, growth hormone-releasing hormone and growth hormone receptor mRNA in diabetic rats. J Neuroendocrinol. 2000 Jan;12(1):29-39.
33 Patel YC, Wheatley T, Zingg HH. Increased blood somatostatin concentration in streptozotocin diabetic rats. Life Sci. 1980 Oct; 27(17):1563-70.

34 Ndon JA, Giustina A, Wehrenberg WB. Hypothalamic regulation of impaired growth hormone secretion in diabetic rats. 1. Studies in streptozotocin-induced diabetic rats. Neuroendocrinology. 1992 May;55(5):500-5.

35 Joanny P, Peyre G, Steinberg J, Guillaume V, Pesce G, Becquet D, et al. Effect of diabetes on in vivo and in vitro hypothalamic somatostatin release. Neuroendocrinology. 1992 May; 55(5):485-91.

36 Bluet-Pajot MT, Durand D, Kordon C. Influence of streptozotocin-induced diabetes on growth hormone secretion in the rat. Neuroendocrinology. 1983;36(4):307-9.

37 Tannenbaum GS. Growth hormone secretory dynamics in streptozotocin diabetes: evidence of a role for endogenous circulating somatostatin. Endocrinology. 1981 Jan;108(1): 76-82.

38 Müller EE. Neural control of somatotropic function. Physiol Rev. 1987 Jul;67(3):962-1053.

39 Olchovsky D, Bruno JF, Wood TL, Gelato MC, Leidy JW Jr, Gilbert JM Jr, et al. Altered pituitary growth hormone $(\mathrm{GH})$ regulation in streptozotocin-diabetic rats: a combined defect of hypothalamic somatostatin and GH-releasing factor. Endocrinology. 1990 Jan;126(1):53-61.

40 Kim E, Sohn S, Lee M, Jung J, Kineman RD, Park S. Differential responses of the growth hormone axis in two rat models of streptozotocin-induced insulinopenic diabetes. J Endocrinol. 2006 Feb;188(2):263-70.

41 Liu K, Paterson AJ, Konrad RJ, Parlow AF, Jimi S, Roh M, et al. Streptozotocin, an OGlcNAcase inhibitor, blunts insulin and growth hormone secretion. Mol Cell Endocrinol. 2002 Aug;194(1-2):135-46.

42 Chapman IM, Hartman ML, Straume M, Johnson ML, Veldhuis JD, Thorner MO. Enhanced sensitivity growth hormone $(\mathrm{GH})$ chemiluminescence assay reveals lower postglucose nadir $\mathrm{GH}$ concentrations in men than women. J Clin Endocrinol Metab. 1994 Jun; 78(6):1312-9.

43 Arafat AM, Möhlig M, Weickert MO, Perschel FH, Purschwitz J, Spranger J, et al. Growth hormone response during oral glucose tolerance test: the impact of assay method on the estimation of reference values in patients with acromegaly and in healthy controls, and the role of gender, age, and body mass index. J Clin Endocrinol Metab. 2008 Apr;93(4):1254-62.

44 Rosário PW, Furtado MS. Growth hormone after oral glucose overload: revision of reference values in normal subjects. Arq Bras Endocrinol Metabol. 2008 Oct;52(7):1139-44.

45 Markkanen H, Pekkarinen T, Välimäki MJ, Alfthan H, Kauppinen-Mäkelin R, Sane T, et al. Effect of sex and assay method on serum concentrations of growth hormone in patients with acromegaly and in healthy controls. Clin Chem. 2006 Mar;52(3):468-73. 
46 Verrua E, Filopanti M, Ronchi CL, Olgiati L, Ferrante E, Giavoli C, et al. GH response to oral glucose tolerance test: a comparison between patients with acromegaly and other pituitary disorders. J Clin Endocrinol Metab. 2011 Jan;96(1):E83-8.

47 Costa AC, Rossi A, Martinelli CE Jr, Machado HR, Moreira AC. Assessment of disease activity in treated acromegalic patients using a sensitive $\mathrm{GH}$ assay: should we achieve strict normal GH levels for a biochemical cure? J Clin Endocrinol Metab. 2002 Jul;87(7):3142-7.

48 Endert E, van Rooden M, Fliers E, Prummel MF, Wiersinga WM. Establishment of reference values for endocrine tests- part V: acromegaly. Neth J Med. 2006 Jul-Aug;64(7):230-5.

49 Colao A, Amato G, Pedroncelli AM, Baldelli R, Grottoli S, Gasco V, et al. Gender- and agerelated differences in the endocrine parameters of acromegaly. J Endocrinol Invest. 2002 Jun;25(6):532-8.

50 Freda PU, Landman RE, Sundeen RE, Post $\mathrm{KD}$. Gender and age in the biochemical assessment of cure of acromegaly. Pituitary. 2001 Aug;4(3):163-71.

51 Dawson-Hughes B, Stern D, Goldman J, Reichlin S. Regulation of growth hormone and somatomedin-C secretion in postmenopausal women: effect of physiological estrogen replacement. J Clin Endocrinol Metab. 1986 Aug;63(2):424-32.

52 Weissberger AJ, Ho KK, Lazarus L. Contrasting effects of oral and transdermal routes of estrogen replacement therapy on 24-hour growth hormone (GH) secretion, insulin-like growth factor I, and GH-binding protein in postmenopausal women. J Clin Endocrinol Metab. 1991 Feb;72(2):374-81.

53 Ciresi A, Amato MC, Pivonello R, Nazzari E, Grasso LF, Minuto F, et al. The metabolic profile in active acromegaly is gender-specific. J Clin Endocrinol Metab. 2013 Jan;98(1):E51-9.

54 Park SH, Ku CR, Moon JH, Kim EH, Kim SH, Lee EJ. Age- and Sex-Specific Differences as Predictors of Surgical Remission among $\mathrm{Pa}$ tients with Acromegaly. J Clin Endocrinol Metab. 2017.

55 Bancos I, Algeciras-Schimnich A, Woodmansee WW, Cullinane AK, Donato LJ, Nippoldt TB, et al. Determination of nadir growth hormone concentration cutoff in patients with acromegaly. Endocr Pract. 2013 Nov-Dec;19(6):937-45.

56 Vierhapper H, Heinze G, Gessl A, Exner M, Bieglmayr C. Use of the oral glucose tolerance test to define remission in acromegaly. Metabolism. $2003 \mathrm{Feb}$;52(2):181-5.

57 Colao A, Pivonello R, Auriemma RS, Grasso LF, Galdiero M, Pivonello C, et al. Growth hormone nadir during oral glucose load depends on waist circumference, gender and age: normative data in 231 healthy subjects. Clin Endocrinol (Oxf). 2011 Feb;74(2):234-40.

58 Rosario P, Santos Salles D, Bessa B, Furtado MS. Nadir growth hormone after oral glucose overload in obese subjects. Arq Bras Endocrinol Metabol. 2010;54(5):507-9.
59 Schilbach K, Sophia Nicolay S, Haenelt M, et al. Diagnosis of acromegaly: Sex and BMI are the major determinants of growth hormone suppression during oral glucose tolerance test (OGTT). Presented at 19th European Congress of Endocrinology, Lisbonne, Portugal. Endocrine Abstracts (2017) 49 GP196, 2017.

60 Iranmanesh A, Lizarralde G, Veldhuis JD. Age and relative adiposity are specific negative determinants of the frequency and amplitude of growth hormone $(\mathrm{GH})$ secretory bursts and the half-life of endogenous GH in healthy men. J Clin Endocrinol Metab. 1991 Nov;73(5):1081-8.

61 Veldhuis JD, Iranmanesh A, Ho KK, Waters MJ, Johnson ML, Lizarralde G. Dual defects in pulsatile growth hormone secretion and clearance subserve the hyposomatotropism of obesity in man. J Clin Endocrinol Metab. 1991 Jan;72(1):51-9.

62 Williams T, Berelowitz M, Joffe SN, Thorner MO, Rivier J, Vale W, et al. Impaired growth hormone responses to growth hormone-releasing factor in obesity. A pituitary defect reversed with weight reduction. $\mathrm{N}$ Engl J Med. 1984 Nov;311(22):1403-7.

63 Ho KY, Evans WS, Blizzard RM, Veldhuis JD, Merriam GR, Samojlik E, et al. Effects of sex and age on the 24-hour profile of growth hormone secretion in man: importance of endogenous estradiol concentrations. J Clin Endocrinol Metab. 1987 Jan;64(1):51-8.

64 Russell-Aulet M, Jaffe CA, Demott-Friberg R, Barkan AL. In vivo semiquantification of hypothalamic growth hormone-releasing hormone (GHRH) output in humans: evidence for relative GHRH deficiency in aging. J Clin Endocrinol Metab. 1999 Oct;84(10):3490-7.

65 Colao A, Pivonello R, Cavallo LM, Gaccione M, Auriemma RS, Esposito F, et al. Age changes the diagnostic accuracy of mean profile and nadir growth hormone levels after oral glucose in postoperative patients with acromegaly. Clin Endocrinol (Oxf). 2006 Aug; 65(2):250-6.

66 Herman-Bonert V, Seliverstov M, Melmed S. Pregnancy in acromegaly: successful therapeutic outcome. J Clin Endocrinol Metab. 1998 Mar;83(3):727-31.

67 Hisano M, Sakata M, Watanabe N, Kitagawa M, Murashima A, Yamaguchi K. An acromegalic woman first diagnosed in pregnancy. Arch Gynecol Obstet. 2006 Jun;274(3):171-3.

68 Obuobie K, Mullik V, Jones C, John R, Rees AE, Davies JS, et al. McCune-Albright syndrome: growth hormone dynamics in pregnancy. J Clin Endocrinol Metab. 2001 Jun; 86(6):2456-8.

69 Dias M, Boguszewski C, Gadelha M, Kasuki L, Musolino N, Vieira JGH, Abucham J. Acromegaly and pregnancy: a prospective study. Eur J Endocrinol. 2013 Dec 21;170(2):301-10.

70 Misra M, Cord J, Prabhakaran R, Miller KK, Klibanski A. Growth hormone suppression after an oral glucose load in children. J Clin Endocrinol Metab. 2007 Dec;92(12):4623-9.
71 Andersen O, Haugaard SB, Hansen BR, Orskov $\mathrm{H}$, Andersen UB, Madsbad S, et al. Different growth hormone sensitivity of target tissues and growth hormone response to glucose in HIV-infected patients with and without lipodystrophy. Scand J Infect Dis. 2004; 36(11-12):832-9.

72 Freda PU, Post KD, Powell JS, Wardlaw SL. Evaluation of disease status with sensitive measures of growth hormone secretion in 60 postoperative patients with acromegaly. J Clin Endocrinol Metab. 1998 Nov;83(11): 3808-16.

73 Serri O, Beauregard C, Hardy J. Long-term biochemical status and disease-related morbidity in 53 postoperative patients with acromegaly. J Clin Endocrinol Metab. 2004 Feb; 89(2):658-61.

74 Trainer PJ, Barth J, Sturgeon C, Wieringaon G. Consensus statement on the standardisation of GH assays. Eur J Endocrinol. 2006 Jul; 155(1):1-2.

75 Clemmons DR. Consensus statement on the standardization and evaluation of growth hormone and insulin-like growth factor assays. Clin Chem. 2011 Apr;57(4):555-9.

76 Celniker AC, Chen AB, Wert RM Jr, Sherman $\mathrm{BM}$. Variability in the quantitation of circulating growth hormone using commercial immunoassays. J Clin Endocrinol Metab. 1989 Feb;68(2):469-76.

77 Bidlingmaier M, Strasburger CJ. Growth hormone assays: current methodologies and their limitations. Pituitary. 2007;10(2):115-9.

78 Bidlingmaier M. Problems with GH assays and strategies toward standardization. Eur J Endocrinol. 2008 Dec;159 Suppl 1:S41-4.

79 Giustina A, Barkan A, Casanueva FF, Cavagnini F, Frohman L, Ho K, et al. Criteria for cure of acromegaly: a consensus statement. J Clin Endocrinol Metab. 2000 Feb;85(2):526-9.

80 Trainer PJ. Editorial: acromegaly-consensus, what consensus? J Clin Endocrinol Metab. 2002 Aug;87(8):3534-6.

81 Freda PU, Reyes CM, Nuruzzaman AT, Sundeen RE, Bruce JN. Basal and glucose-suppressed GH levels less than $1 \mathrm{microg} / \mathrm{L}$ in newly diagnosed acromegaly. Pituitary. 2003; 6(4):175-80.

82 Dimaraki EV, Jaffe CA, DeMott-Friberg R, Chandler WF, Barkan AL. Acromegaly with apparently normal GH secretion: implications for diagnosis and follow-up. J Clin Endocrinol Metab. 2002 Aug;87(8):3537-42.

83 Ribeiro-Oliveira A Jr, Faje AT, Barkan AL. Limited utility of oral glucose tolerance test in biochemically active acromegaly. Eur J Endocrinol. 2011 Jan;164(1):17-22.

84 Landis CA, Harsh G, Lyons J, Davis RL, McCormick F, Bourne HR. Clinical characteristics of acromegalic patients whose pituitary tumors contain mutant Gs protein. J Clin Endocrinol Metab. 1990 Dec;71(6):1416-20.

85 Ribeiro-Oliveira A Jr, Barkan A. The changing face of acromegaly-advances in diagnosis and treatment. Nat Rev Endocrinol. 2012 Oct;8(10):605-11. 
86 Adams EF, Brockmeier S, Friedmann E, Roth M, Buchfelder M, Fahlbusch R. Clinical and biochemical characteristics of acromegalic patients harboring gsp-positive and gsp-negative pituitary tumors. Neurosurgery. 1993 Aug;33(2):198-203.

87 Buchfelder M, Fahlbusch R, Merz T, Symowski $\mathrm{H}$, Adams EF. Clinical correlates in acromegalic patients with pituitary tumors expressing GSP oncogenes. Pituitary. 1999 May;1(3-4): 181-5.

88 Occhi G, Losa M, Albiger N, Trivellin G, Regazzo $\mathrm{D}$, Scanarini $\mathrm{M}$, et al. The glucose-dependent insulinotropic polypeptide receptor is overexpressed amongst GNAS1 mutationnegative somatotropinomas and drives growth hormone $(\mathrm{GH})$-promoter activity in GH3 cells. J Neuroendocrinol. 2011 Jul;23(7): 641-9.

89 Scaroni C, Albiger N, Daniele A, Dassie F, Romualdi C, Vazza G, et al. Paradoxical GH increase during OGTT is associated to first-generation somatostatin analogs responsiveness in acromegaly. J Clin Endocrinol Metab. 2019 Mar;104(3):856-62.

90 Mukai K, Otsuki M, Tamada D, Kitamura T, Hayashi R, Saiki A, Goto Y, Arita H, Oshino S, Morii E, Saitoh Y, Shimomura I. Clinical characteristics of acromegalic patients with paradoxical growth hormone response to oral glucose load. J Clin Endocrinol Metab. 2018 Nov 23.

91 Beck P, Parker ML, Daughaday WH. Paradoxical hypersecretion of growth hormone in response to glucose. J Clin Endocrinol Metab. 1966 Apr;26(4):463-9.

92 Hunter WM, Clarke BF, Duncan LJ. Plasma growth hormone after an overnight fast and following glucose loading in healthy and diabetic subjects. Metabolism. 1966 Jul;15(7): 596-607.

93 Becker MD, Cook GC, Wright AD. Paradoxical elevation of growth hormone in active chronic hepatitis. Lancet. 1969 Nov;2(7629): 1035-9.
94 Grecu EO, Walter RM Jr, Gold EM. Paradoxical release of growth hormone during oral glucose tolerance test in patients with abnormal glucose tolerance. Metabolism. 1983 Feb; 32(2):134-7.

95 Ribeiro-Oliveira A Jr, Abrantes MM, Barkan AL. Complex rhythmicity and age dependence of growth hormone secretion are preserved in patients with acromegaly: further evidence for a present hypothalamic control of pituitary somatotropinomas. J Clin Endocrinol Metab. 2013 Jul;98(7):2959-66.

96 Hage M, Chaligne R, Viengchareun S, Villa C, Salenave S, Bouligand J, Letouzé E, Tosca L, Rouquette A, Tachdjian G, Parker F, Lombès $\mathrm{M}$, Lacroix A, Gaillard S, Chanson P, Kamenický P. Hypermethylator phenotype and ectopic GIP receptor in GNAS mutation-negative somatotropinomas. J Clin Endocrinol Metab. 2018 Oct 29.

97 Hage M, Viengchareun S, Brunet E, Villa C, Pineau D, Bouligand J, et al. Genomic Alterations and Complex Subclonal Architecture in Sporadic GH-Secreting Pituitary Adenomas. J Clin Endocrinol Metab. 2018 May;103(5):1929-39.

98 Valcavi R. Oral glucose tolerance test: an inhibitory or a stimulatory input to growth hormone secretion? J Endocrinol Invest. 1996 Apr;19(4):253-5.

99 Lacroix A, Bolté E, Tremblay J, Dupré J, Poitras $\mathrm{P}$, Fournier H, et al. Gastric inhibitory polypeptide-dependent cortisol hypersecretion-a new cause of Cushing's syndrome. N Engl J Med. 1992 Oct;327(14):974-80.

100 Reznik Y, Allali-Zerah V, Chayvialle JA, Leroyer R, Leymarie P, Travert G, et al. Fooddependent Cushing's syndrome mediated by aberrant adrenal sensitivity to gastric inhibitory polypeptide. N Engl J Med. 1992 Oct;327(14):981-6.

101 Lecoq AL, Stratakis CA, Viengchareun S, Chaligné R, Tosca L, Deméocq V, et al. Adrenal GIPR expression and chromosome 19q13 microduplications in GIP-dependent Cushing's syndrome. JCI Insight. 2017 Sep; $2(18): 2$.
102 Umahara M, Okada S, Ohshima K, Mori M Glucose-dependent insulinotropic polypeptide induced growth hormone secretion in acromegaly. Endocr J. 2003 Oct;50(5):643-50.

103 Regazzo D, Losa M, Albiger NM, Terreni MR, Vazza G, Ceccato F, et al. The GIP/ GIPR axis is functionally linked to GH-secretion increase in a significant proportion of gsp- somatotropinomas. Eur J Endocrinol. 2017 May;176(5):543-53.

104 Melmed S, Bronstein MD, Chanson P, Klibanski A, Casanueva FF, Wass JA, et al. A Consensus Statement on acromegaly therapeutic outcomes. Nat Rev Endocrinol. 2018 Sep;14(9):552-61.

105 Carmichael JD, Bonert VS, Mirocha JM, Melmed S. The utility of oral glucose tolerance testing for diagnosis and assessment of treatment outcomes in 166 patients with acromegaly. J Clin Endocrinol Metab. 2009 Feb;94(2): 523-7.

106 Melmed S, Colao A, Barkan A, Molitch M Grossman AB, Kleinberg D, et al.; Acromegaly Consensus Group. Guidelines for acromegaly management: an update. J Clin Endocrinol Metab. 2009 May;94(5):1509-17.

107 Christiansen Arlien-Søborg M, Trolle C, Alvarson E, Bæk A, Dal J, Otto Lunde Jørgensen J. Biochemical assessment of disease control in acromegaly: reappraisal of the glucose suppression test in somatostatin analogue (SA) treated patients. Endocrine. 2017 Jun;56(3): $589-94$.

108 Dal J, Klose M, Heck A, Andersen M, Kistorp C, Nielsen EH, Bollerslev J, Feldt-Rasmussen U, Jørgensen JOL. Targeting either GH or IGF-I during somatostatin analogue treatment in patients with acromegaly: a randomized multicentre study. Eur J Endocrinol. 2018 Jan;178(1):65-74.

109 Rubeck KZ, Madsen M, Andreasen CM, Fisker S, Frystyk J, Jørgensen JOL. Conventional and novel biomarkers of treatment outcome in patients with acromegaly: discordant results after somatostatin analog treatment compared with surgery. Eur J Endocrinol. 2010 Nov;163(5):717-26. 